\title{
Radiological progress report of curing scoliosis according to the fed method based on own material
}

\author{
Zbigniew Śliwiński ${ }^{1 *}$, Wojciech Kufel ${ }^{1}$, Bartłomiej Halat ${ }^{1}$, Beata Michalak¹, Danuta Śliwińska', Grzegorz Śliwiński \\ From 11th International Conference on Conservative Management of Spinal Deformities - SOSORT 2014 \\ Annual Meeting \\ Wiesbaden, Germany. 8-10 May 2014
}

\section{Introduction}

In the process of treating scoliosis X-ray is one of the objective methods of assessing the progress of therapy. In the assessment of scoliosis picture should cover the entire spine, hip bones with plates and hips, made standing in the AP and lateral projections. On the basis of a well-made images, you can specify the parameters of scoliosis (type of scoliosis, Risser test, the Cobb angle, the angle of rotation of the vertebrae, the index kifo lordosis, etc.) which allows the selection of the proper physiotherapy and assessment of treatment effects.

\section{Materials and methods}

We evaluated a group of 70 children diagnosed with idiopathic scoliosis in age from 7 to 18 years residing in the treatment by the Fed at the Centre for Rehabilitation in Zgorzelec. The children remained in the two monthly turnusach apart semester. During the stay twice a day participated in therapy by the Fed. Analysis and evaluation of X-ray were performed before treatment and at the end of the half-year stage. With images were evaluated Cobb angle, vertebral rotation by raimondii test Risser, type of scoliosis by King-Moe.

\section{Results}

The results have been developed in the form of tables and charts, broken down by the scoliosis to $20^{\circ}, 30^{\circ}, 40^{\circ}$ and above $40^{\circ}$.

\section{Conclusions}

Comparison of X-ray images is one of objective assessment in the treatment of scoliosis. The results presented in the study are the evaluation of the effectiveness of the method the Fed.

\section{Authors' details}

${ }^{1}$ Physiotherapy Center Zgorzelec, Zgorzelec, Poland. ${ }^{2}$ Dresden University of Technology - Institute of Biomedical Engineering, Dresden, Germany.

Published: 4 December 2014

\section{doi:10.1186/1748-7161-9-S1-P14}

Cite this article as: Śliwiński et al:: Radiological progress report of curing scoliosis according to the fed method based on own material. Scoliosis 2014 9(Suppl 1):P14.

PPhysiotherapy Center Zgorzelec, Zgorzelec, Poland

Full list of author information is available at the end of the article

Submit your next manuscript to BioMed Central and take full advantage of:

- Convenient online submission

- Thorough peer review

- No space constraints or color figure charges

- Immediate publication on acceptance

- Inclusion in PubMed, CAS, Scopus and Google Scholar

- Research which is freely available for redistribution

Submit your manuscript at www.biomedcentral.com/submit
() Biomed Central 